\title{
3. A Source of Power, Disquiet and Biblical Purport: The Jordan River in Santo, Vanuatu
}

\section{Introduction}

The Jordan River, on the island of Espíritu Santo, is the largest river in the Vanuatu archipelago. ${ }^{1}$ It was originally given that name 400 years ago by a foreigner, Iberian navigator Pedro Fernández de Quirós, the first of many outlanders who have since engaged with the people and environments that coexist with this body of flowing water. Of course, contemporary Santo Islanders have their own names for this river, as well as for the specific tributaries that give form to its drainage basin. The rugged geography over which this basin extends is located within a broader, geographically complex region of North Santo. This territory, to whose description I return below, is host to a rich diversity of ni-Vanuatu communities, language groups and storied places. ${ }^{2}$ Importantly, this is

1 For the purposes of this paper, I focus on the part of the Jordan that constitutes the large, slowly flowing body of water that snakes across and gives form to the lowland and coastal delta of Big Bay. This geography includes the 'mouth' of the river, which is characterised by a shifting series of marshes and unstable waterways that empty, with very little strength, into Big Bay itself.

2 The island of Espiritu Santo is home to at least 15, and possibly as many as 28, separate language communities (Tryon 1996; Lynch and Crowley 2001: 43-58). 
a territory that is powerfully shaped and characterised by multifarious forms of salt and fresh water; rivers, creeks, waterfalls, marshes, springs and man-made terraces for the cultivation of water taro are only part of the watery phenomena that have produced the North Santo landscape over the course of hundreds and even thousands of years.

The aim of this chapter is to explore the human and environmental diversity of this North Santo waterscape through the layered stories of mobility and belonging by which local communities relate to their watery surroundings. Specifically, my chapter is about water-related geographical identities in relation to the contested past, and to the uncertainties of movement and transformation that are experienced in connection with physical and spiritual sites of fresh water and flowing water. It is worth emphasising that references to these tangible and intangible sources of fresh water-be they the rivers, waterfalls and springs, or watery spiritsare necessarily inflected with morally laden values that sometimes work as powerful, prescriptive reminders of the behaviour that humans and nonhumans must exhibit towards each other and towards significant aspects of their circumambient spaces. In this regard, fresh water, especially as personified by the Jordan River and various important springs, is a critical aspect of the mutual constitution of persons and land, understood as a broader, multi-layered phenomenon. Thus, this text is about the genealogical and moral dimensions of the waterscape of North Santo in relation to what Biersack (1990) once defined as the process of 'history in the making', which is premised on land and genealogies of belonging.

Because this chapter is about geographical identity, as opposed to simply 'territorial' identity (Mondragón 2009), it is worth remarking that the exploration of territory and identity has long been the subject of anthropological scrutiny in Vanuatu research (e.g. Lane 1971; Rodman 1987; Bonnemaison 1996; Hess 2009; Mondragón 2012, 2015a, 2015b). These important contributions have given rise to key insights about images of rootedness and mobility among the different island communities that make up the archipelago (see also Bonnemaison 1994, 1997; Jolly 1999; Taylor 2008). Here, however, I foreground water and not land as my primary object of interest. It is my intention to extend understandings of territoriality to the often ignored watery sites of the land by highlighting some of the ways in which these places are enmeshed in the imagination of kinship, human/non-human relations, land use and belonging in North Santo. 
My use of the term 'waterscape' in this chapter is partly informed by Baviskar's use of the term in order to evoke layered ecologies, as constituted through historical, environmental and political concerns (Baviskar 2007). But, in contrast to Baviskar's focus on 'struggles over water', my primary interest is to address the themes that recur through this volume by focusing on the neglected moral, spiritual and agentive 'layers' of fresh water, history and cultural landscapes in island Melanesia. ${ }^{3}$

The materials in this paper are intended to begin to address the interleaving of fluid and territorial localities, in time and space, as relevant frames from which to approach the ongoing shifts and transformations that inform North Santo experiences of geographic belonging. In particular, my interest in layered geographies is focused on contested pasts and on the disquiet that accompanies boundary work in the expression of belonging-in other words, the ongoing iteration and contestation connected to places of origin, processes of movement and emerging sites of transformation. The focus on layering is intended as a way of emphasising that humanenvironmental relations across North Santo are premised on a broad panoply of processes, rather than structures or types. In other words, I am interested in exploring the particular processes that make up the 'living milieu' of North Vanuatu societies (Mondragón 2009).

In the ethnographic and historical materials that follow, I have taken a cluster of powerful toponyms associated with the River Jordan as my point of departure for this exploration of the mutually constituted waterscapes that partially reflect what Fox (2006) has termed 'topogenies', and that inform the watery micro-geography of North Santo.

\section{The North Santo Context}

The island of Espiritu Santo, known commonly as Santo, is located in the north-central area of the Vanuatu archipelago. With a surface area of $3,955.5 \mathrm{~km}^{2}$, and a north-south length of more than $50 \mathrm{~km}$, Santo is the largest island in Vanuatu (Siméoni 2009). It hosts the archipelago's greatest concentration of socio-linguistic and (purportedly) biological diversity (see Tzérikiantz 2008; Mondragón forthcoming). Its many distinctive physical traits include Vanuatu's highest mountain (Tabwemasana), longest river (the Jordan), largest protected harbour (Big Bay) and the

3 See Boomgarden (2007) for a similar approach in a neighbouring culture region. 
Cumberland Peninsula (see Figures 3.1 and 3.2). Because it is the primary area in which most of the events recounted in this chapter take place, the following is a summary explication of the major sub-regions that surround and give form to Big Bay.

The west coast is the most distant and isolated part of North Santo, when compared to the southern part of the island and the town of Luganville, where Vanuatu's second-largest service sector and airport are located. The shoreline of West Santo is characterised by a very narrow set of beaches lying at the bottom of sharply vertical mountain ranges that tower over the ocean with an average height of more than $1,000 \mathrm{~m}$ and host some of the richest remaining areas of high-value timber in Vanuatu. This mountainous wall stretches north, all the way to the tip of the Cumberland Peninsula, and is a product of ongoing and intense seismic uplifts. ${ }^{4}$

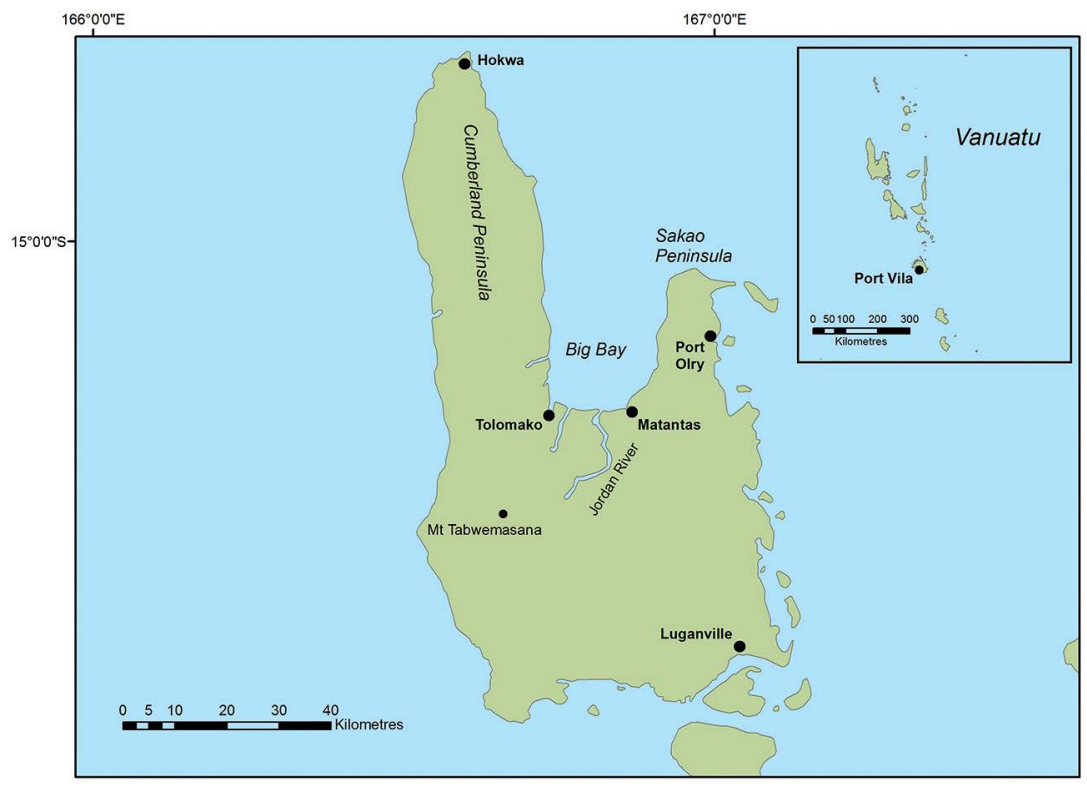

Figure 3.1 North Santo and the Jordan.

Source: Cartography by Jerry Jacka.

4 Santo lies across the junction between the Australian and Pacific tectonic plates. 


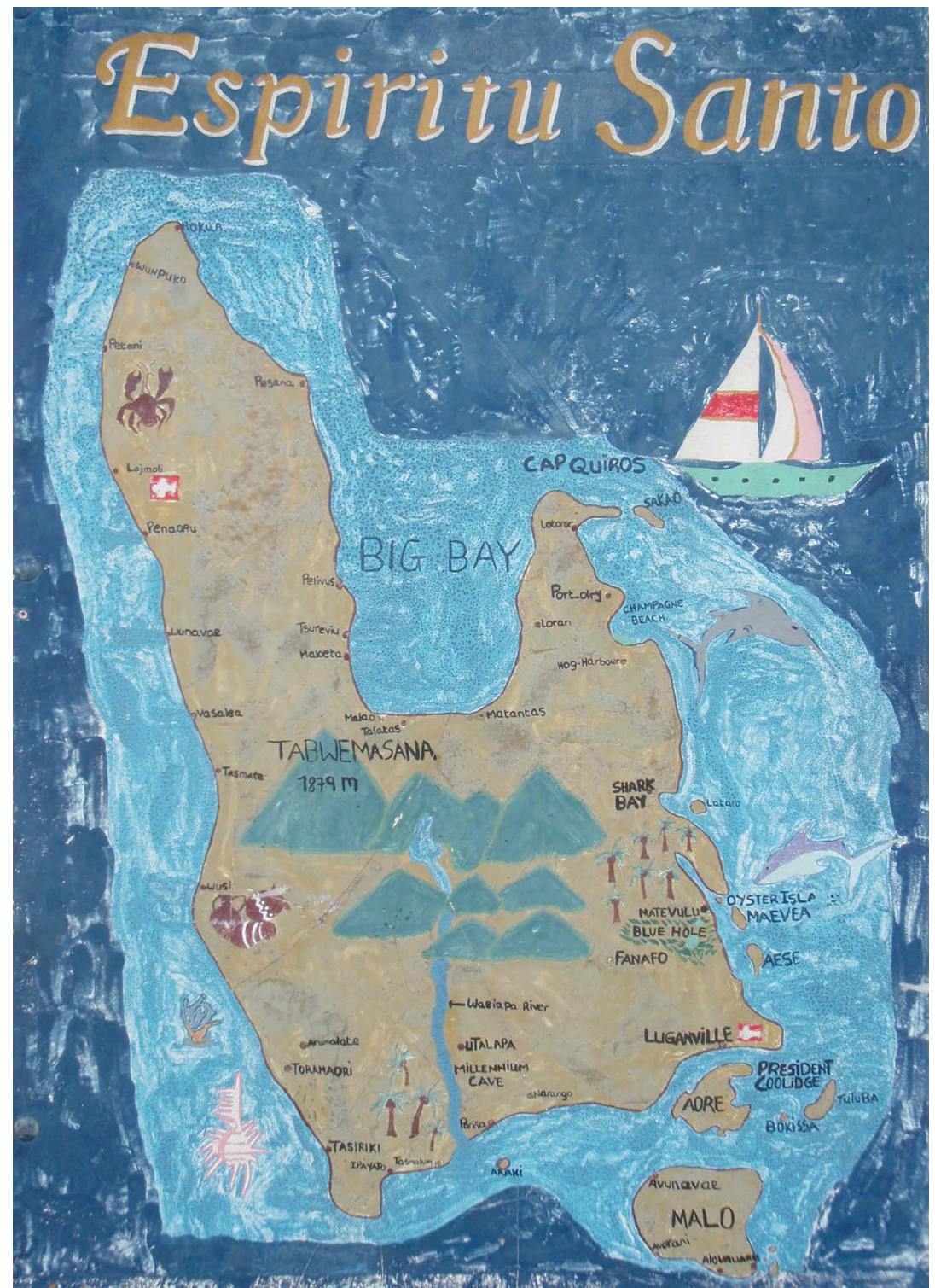

Figure 3.2 The Santo waterscape, as viewed from the south. ${ }^{5}$

Source: Photo by the author, 2010.

5 Note that the Jordan is not even represented on this tourist billboard in Luganville, even though it is the largest body of water on the island. In comparison, the river that is represented here as running from north to south is in fact much smaller and shorter than the Jordan; however, it is becoming a popular destination for adventure tourism day trips, and that perhaps explains its prominence in the imagination of some of the townspeople. 
At present, the west coast hosts a few small and scattered coastal settlements whose only quotidian access to Luganville and the south is through motorboat routes that are neither regular nor economically accessible to most local villagers. The most frequent runs are operated by boat owners ferrying agricultural produce to southwest coast villages whose inhabitants then drive these crops to the urban market. The extremely rugged interior of the west coast is dominated by the presence of Mt Tabwemasana, which, at $1,879 \mathrm{~m}$, is Vanuatu's highest mountain, and the third-highest peak in the Pacific Islands outside of New Guinea, Hawai' $i$ and New Zealand. The headwaters of the Jordan River originate in the high gullies surrounding Tabwemasana, an area that is isolated and very sparsely populated as a result of the forceful displacement of most interior villages to the west coast during late condominium times. ${ }^{6}$ Jean Guiart wrote an account of this high region following his trek through several of its communities in the mid-1950s (Guiart 1958).

In contrast with the western half of the island, the shoreline of East Santo is characterised by relatively flat ground endowed with rich soils. For this reason it became one of the premium territories for the establishment of cattle farming and copra plantations during the colonial era. The transformations of this farming legacy survive to this day, but over the past decade this territory has begun to experience a new bout of change as a result of two factors: first, the indiscriminate, speculative and often illegal purchase of coastal tracts by Australian developers; and second, the completion, in 2009, of a two-lane blacktop built with funding from the Millennium Challenge Account, which was established and supported primarily by the United States Government. Consequently, the ni-Vanuatu settlements of the east coast are more numerous, more densely populated and readily connect to Luganville. This explains the predominance of several east coast communities within important sectors of the Luganville economy, most notably public transport and stevedoring.

Big Bay is a very large U-shaped formation that lies between the extended arms of the Cumberland Peninsula to the west and the much smaller Sakao Peninsula to the east (see Figure 3.3). The total maritime surface encompassed by Big Bay is considerable-one cannot see the ends of its peninsular arms from the southern end of the bay, and it takes eight hours

6 The British and French jointly governed Vanuatu from 1906 to 1980 under the authority of an agreement known as the British-French Condominium. Vanuatu became an independent country in 1980 (MacClancy 2002). 
to traverse it lengthwise by sea, in good weather, along the most extended western shoreline below the Cumberland mountain range. The extended region of tropical forest that rests beyond the shoreline of the black sand beaches at the bottom of the bay is sparsely populated and watered by a meandering network of streams and rivers that variously feed into, and extend out from, the mouth of the Jordan River, which empties almost exactly at the centre of the cul-de-sac that forms Big Bay's interior end. The only access into this area is by two dirt tracks: one that cuts across 'bush' Santo from the south, and has been developed by various logging companies over the past 20 years; and the second that cuts across the eastern ridge of the Sakao Peninsula and connects with the East Santo road that leads down to Luganville.

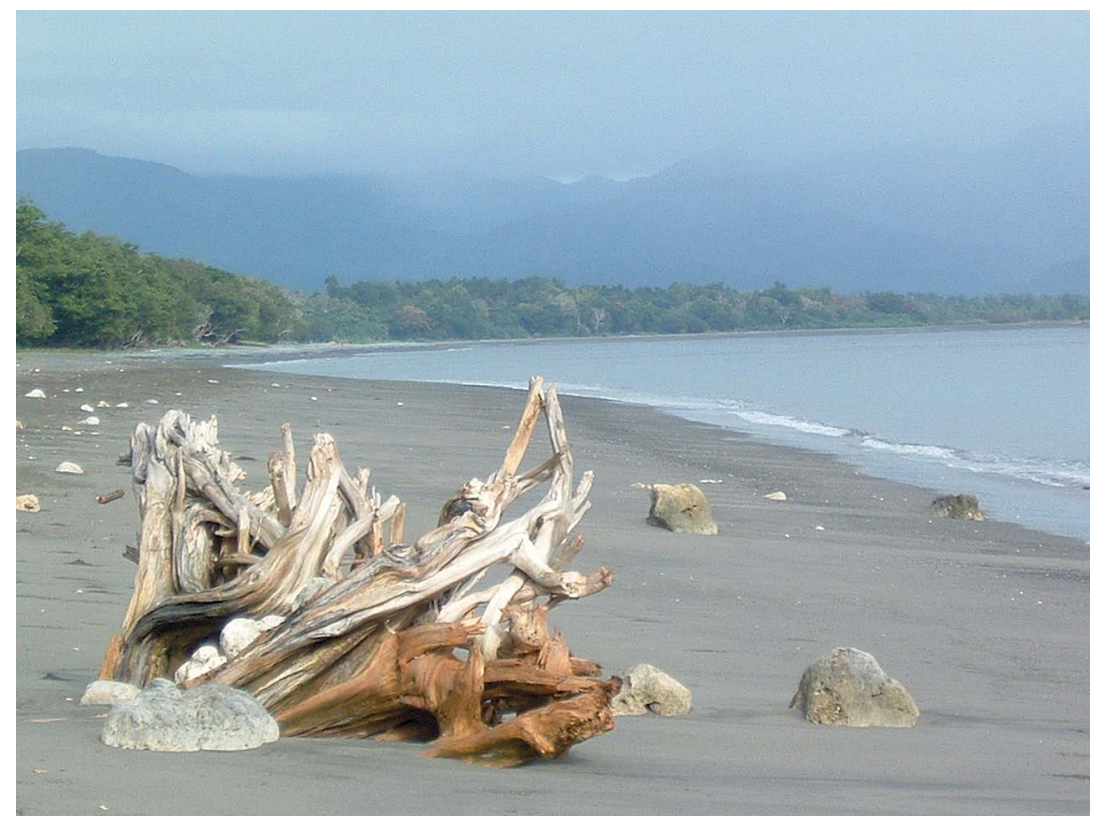

Figure 3.3 The shore of Big Bay, facing the western, mountainous interior of Santo, as viewed from Matantas.

Source: Photo by the author.

Importantly, both tracks end at the southeastern corner of Big Bay, which is capped by the coastal village of Matantas. The only other road into North Santo is a dirt track that turns off from the Luganville-Matantas bush track, winds its way west across the Jordan and eventually forks again to reach the remote coastal settlements of Malao and Tolomako. Traffic 
along this western bush track is minimal since neither of those communities represents a major point for the transfer of goods or people. Beyond them, into the bush and the huge mass of the Cumberland Peninsula, there are no more roads. It is for this reason that Matantas constitutes the major point of entry and departure for vehicles coming and going from the south of Santo, and, conversely, for the motorboats that service the scattered communities of the western shore of the Cumberland Peninsula. Hence, Matantas features prominently as a crossroads for the movement of people and things (consumer goods, exchange items, tools, animals and many other objects) into and out of Big Bay. Not surprisingly, the people of this small community-less than eight extended families totalling around 200 permanent residents over the course of the past decadehave reaped ongoing benefits from their situation as middlepersons, as well as sea and land transport owners, in relation to other Big Bay and East Santo communities. As I explain in the final section of this chapter, the socio-economic prominence of contemporary Matantas, in relation to the rest of North Santo, is further enhanced by the awe that it also inspires through one of its powerful places: a freshwater spring and its spirit guardian, present in numerous local accounts relating to the origin and continuity of Santo Island.

Beyond Big Bay, the single most important environmental feature associated with the waterscape of North Santo, other than the Jordan River, is the extraordinary complex of terraces and canals that characterise large tracts of the steep mountainsides of the Cumberland Peninsula. These enormous irrigation works are indispensable to the proper maintenance of the staple cultivar of Cumberland Peninsula communities-namely, the water taro (Colocasia esculenta) (see Figure 3.4). As such, they are an impressive testament to the long and continuing history of major human modifications to the North Santo landscape and waterscape going back at least several hundred years. They also help to explain the prominence of wetland animals, water taro, waterfalls and natural springs (these last two being of critical importance to irrigation terraces) as entities closely tied to the origins of the river and to some of the principal North Santo lineages, to which I now turn. 


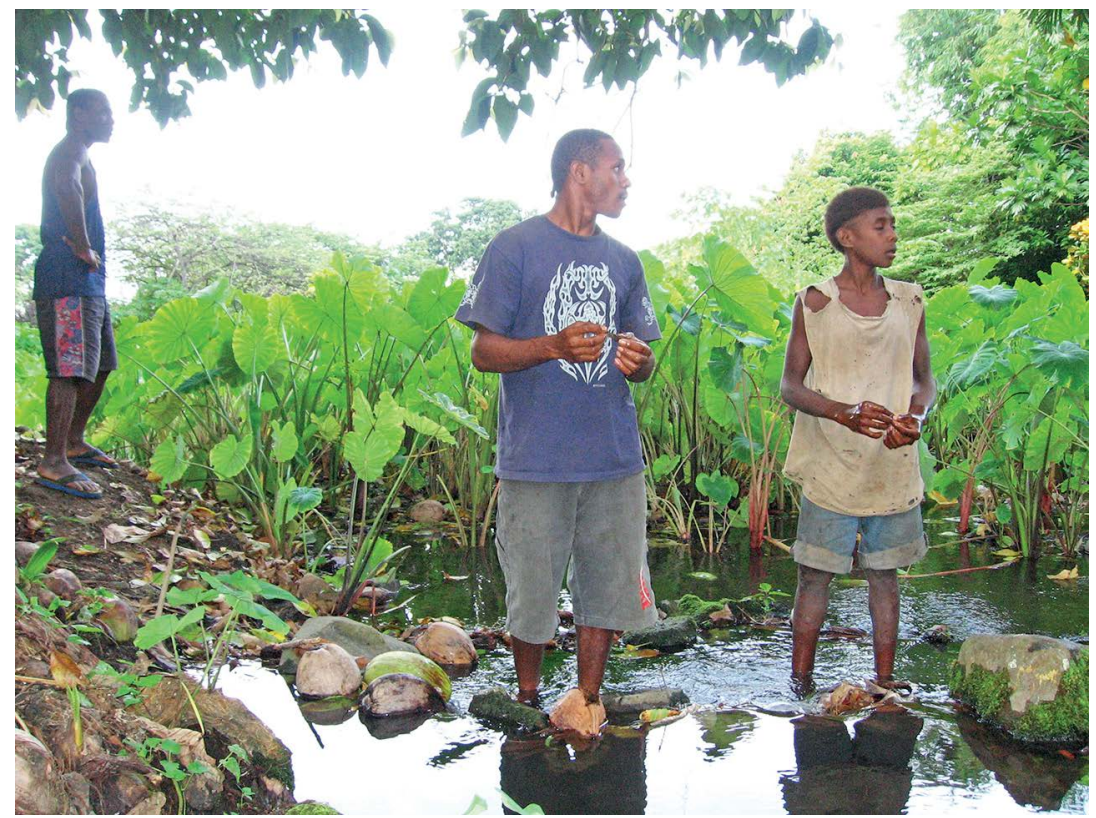

Figure 3.4 Water taro near the village of Hokwa (Cumberland Peninsula). Source: Photo by the author, 2008.

\section{Stories of Origins and North Santo Topogeny}

The most frequent exegetical reference that emerges in relation to the origin of the Jordan River is the kastom stori ('customary story' in Bislama) ${ }^{7}$ that has become the most commonly accepted 'origin myth' for this waterway among the approximately 10 different language communities native to the North Santo region (Lynch and Crowley 2001: 45).

In brief, the Jordan is said to be made up of two smaller rivers- the Ora and the Lape (or Labe) - which exist as smaller, separate tributaries that come together at the upper end of its extensive watershed. The Lape is said to be the stronger of the two, and this appears to be proven by the large amount of trees that are swept from its banks and carried downstream by its powerful current. The following is a summary version of this kastom stori:

7 Bislama is a Vanuatu pidgin that functions as the lingua franca for all ni-Vanuatu. 
In a previous time, when the wind blew through the trees and brought their sound to the sea below [in Big Bay], the salt water exclaimed in fright, 'Oh! this river wants to break through and dump its rubbish on me. I shall stop it.' It therefore held the Labe back by building up the coastline at the mouth of the Jordan with sand and stones. The Labe could no longer reach the sea.

Meantime, the other tributary, the Ora, was slow and hid the rumour of its waters by dampening it with the plentiful stands of burao [cottonwood] trees that line its banks. Upon seeing that the various mouths of the river delta were blocked up, it conferred with the Labe in order that they should join forces and break through to the sea. Hence the Ora, being the one who offered itself as the 'foundation' for their joint endeavour, remains the dominant one, and its waters are on 'top' all the way from where it joins the Labe and down to the bay, and this is why the Jordan is often simply known as the Ora. People make offerings to it, and recognise it as one of the primordial spirits that created and sustain Santo Island.

That is how both tributaries come together, as we see them today. Through their joint force they just manage to constantly carve out small outlets through the pebble-strewn shoreline of Big Bay, and empty out into the sea, which cannot hold them both back. However, the salt water continues to try, and this is why the Jordan is known to be an unstable, powerful presence [described as pe mo la hou soko ri, 'water that shifts all about'/'that does not keep its bounds', in the North Santo languages of Sakao and Tolomako], whose spirit can dig out nambanga [banyan] trees by the roots or go into the forest if it wants.

This origin story speaks to the notion that the river is the manifestation of multiple, supernatural presences, and is a truly extraordinary entity with a will and a way that are not always benign to humans. Today, there are several dozen small communities scattered across the lower and upper Jordan basin whose inhabitants relate closely to the river, and to the animals and physical features that characterise its overall environs. In order to begin to understand the significance and depth of the humanenvironmental bonds that link the inhabitants of these places with their watery surroundings, it is necessary to obtain a general outline of the principal kin groups by which North Santo people identify and position themselves in relation to their circumambient spaces. As we shall see, the close proximity of human genealogical patterns and experiences of the environment with the powerful, morally laden and living features 
of the North Santo waterscape becomes evident upon a cursory examination of the names and origin stories associated with the major kin groups and lineages of this region. ${ }^{8}$

The social organisation of all North Santo communities is premised on matrilateral cross-cousin marriage, and very closely mirrors the general pattern of two opposed halves, or moieties, by which almost all other north-central Vanuatu societies organise their kin dynamics. ${ }^{9}$ These moieties can be referred to as mama laen (matriline in Bislama), but they are more commonly known by the local term navugu, which seems to be the same across at least four of the different language communities proper to Big Bay. In accordance with the structure of most other North Vanuatu kinship groupings, each navugu acts as a matrilineal kin group that, in turn, encompasses several 'family lines'-famle laen in Bislama, natau in Big Bay languages. It is the natau that constitute the specific lineages that act like extended but coherent parties within the context of the ritualised exchange of persons and territory that make up the essence of reciprocity in these islands. Importantly, these moieties and family lines are not simply floating categories for a prescriptive 'system' of kin naming and relating. Because they derive their existence from placebased ancestors and forces, they are mutually constitutive of land and the broader environment. In a sense, they are a part of the living milieu of the landscape and waterscape at issue, and it is important to understand them as one of the ways in which personhood and belonging are made manifest. This is especially relevant in light of the moral dimensions of behaviour that are carried across in the kastom stori that I relate and refer to in the rest of this section.

The names of the two major navugu that operate across all of North Santo, and even extend into West Santo, are Navugu Maliu and Navugu Ova. The first of these names makes reference to the maliu, a net of local design that is employed for catching freshwater lobster, and which represents one

8 The following overview of some of the principal Big Bay kin groups, origin stories and their various relations to animal and hydrological features of the North Santo environment was possible thanks to a number of explanations (some tremendously detailed) that were proffered to me by Billy Tavue of Matantas over the course of several visits to his home. These materials were also greatly enhanced during a unique conversation that I was fortunate to have had with four kind and knowledgeable ladies_-Naomi Wargongon, Vera Alavanua, Eslie Guru and Roslin Iaruel—who hail from different settlements on the east coast of the Cumberland Peninsula facing Big Bay. I remain indebted to all of them, and other Big Bay inhabitants, for their expert assistance and generosity.

9 The Torres Islands, at the far northern extreme of Vanuatu, offer an interesting exception to this system of opposed matrilines (Mondragón 2015b). 
of the significant objects by which North Santo people distinguish their kastom from that of other ni-Vanuatu communities. For its part, the name Navugu Ova refers to the ova, or white heron, which makes its home in the swampy terrain that characterises the mouth and the lower basin of the Jordan River, and also fishes in the shallows by the seashore, and is therefore often described as a 'bird of the sea'.

Each of these navugu, in turn, encompasses a number of different natau whose names are shown in Table 3.1.

Table 3.1 Some prominent kin groups of North Santo.

\begin{tabular}{|l|l|}
\hline Navugu Maliu & Navugu Ova \\
\hline $\begin{array}{l}\text { Natau Marae (named after the saltwater } \\
\text { eel). This natau emerged from, and is } \\
\text { associated with, Natau Hoaka, which } \\
\text { no longer exists, and was named after a } \\
\text { flowering plant with red and white flowers. }\end{array}$ & $\begin{array}{l}\text { Natau Via, named after the wild taro, and } \\
\text { said to be an offshoot of Natau Wuhu Ova } \\
\text { (below). }\end{array}$ \\
\hline $\begin{array}{l}\text { Natau Taupala, named after the action of } \\
\text { securing a pig bone. This originated as an } \\
\text { offshoot of Natau Haviha, which no longer } \\
\text { exists in Big Bay but is still extant on the } \\
\text { west coast of Santo. }\end{array}$ & $\begin{array}{l}\text { Natau Peta, named after the water taro. } \\
\text { meaning 'natau of the eye'. }\end{array}$ \\
\hline $\begin{array}{l}\text { Natau Hocho, named after the action of } \\
\text { tearing the meat from the bone of the pig. } \\
\begin{array}{l}\text { Also originated as an offshoot of Natau } \\
\text { Haviha. }\end{array}\end{array}$ & $\begin{array}{l}\text { Natau Sarau, the meaning of whose name } \\
\text { has not been recovered. }\end{array}$ \\
\hline $\begin{array}{l}\text { Natau la Piho (or Natau Wupoe), which is } \\
\text { simply named after the pig. }\end{array}$ & $\begin{array}{l}\text { Natau Vukarae, named after the flying fox, } \\
\text { and said to be an offshoot of Natau Wuhu } \\
\text { Ova (below). }\end{array}$ \\
\hline $\begin{array}{l}\text { Natau Maliu, named after a net used for } \\
\text { catching freshwater lobster. }\end{array}$ & $\begin{array}{l}\text { Natau Wuhu Ova, named after the } \\
\text { white heron'. }\end{array}$ \\
\hline
\end{tabular}

Source: Compiled by the author from various fieldwork interviews with speakers of Sakao, Tolomako, Vunapu and Piamatsina languages.

The names given to the natau in the above table are not arbitrary, nor are they simply 'metaphorical' or representative of 'totemic' associations. In fact, they almost invariably refer to key creatures or naming events that are present in the origin myths of each natau. Hence, almost all of the creatures or objects that emerge in these names (pig, eel, water taro, net) tend to be the points of origin of each respective natau, or are strongly associated with the entities from which they originate. More important, they are almost all associated with powerful watery places. The shared 
origin story of Natau Pala and Natau Hocho offers a good example of these genealogical and topographical entanglements between water and persons:

Long ago, there were two sisters from Natau Haviha who had two girls each. They lived by the side of the Piavohoho River [a major tributary of the Jordan, on the southwestern interior of Big Bay], but were only able to give their children cabbage and the leaves of trees to eat, for they had no animals and no hunting skills.

One day, crying, the taller of the two sisters reached Septulahia, a place where there is a pool with a hole in its stony bottom into which a big waterfall enters and goes underground. This is the stone house of a powerful navarie [a freshwater spirit]. To one side of the pool there was a tree blooming with leaves, but as the tall sister climbed it, the tree fell into the pool. You see, in a fit of maliciousness her shorter sister had cut the base of the tree. The tall sister fell into the stone home of the navarie, who was dwelling inside with his wife.

After some time, her two girls went out to look for their mother, whereupon the navarie appeared before them and told them that she was safe in his home. The spirit then went hunting for pig in order to give them proper food. However, being generous and powerful, the spirit shared the pig with both the tall and the short sister, as well as their offspring.

Since she was considerate, the taller of the sisters held the bones of the pig, with soft, delicious meat still clinging to it, for her shorter sister to pull off and eat, because she did not know how to eat bone marrow. When they finished eating, the navarie, having fed them and thereby become a father to them, decided that the taller sister would become the origin mother of a new natau, which it named Natau Pala, the natau of she who held the pig bone fast. The shorter sister, meantime, would become the origin ancestor for Natau Hocho, the natau of those who tear the meat from the bone of the pig.

This is the story of how those two natau emerged, and that is why the lands around Piavohoho and Septualahia are known to be the ancestral territory of these two lines. Today, many of the members of these two natau still live close to their places of origin, and can be found dwelling in the villages of Piamaleto and Pialuplup [in the southern part of the Cumberland Peninsula, facing Big Bay].

Lest the binary opposition of Navugu Maliu and Navugu Ova seem a clear-cut exemplar of a more fundamental 'structure' in Santo and North Vanuatu kinship, it bears remarking that the origin stories of the 
navugu of Big Bay consistently mention the existence of at least one other navugu, which is known to have existed and played a major role in the patterns of ritualised exchange between the natau, but disappeared in the recent past. The same is true for at least two or three natau that are known to have existed but are no longer extant. The lesson here is clear: kin relations are modelled on ideal, prescriptive types of reciprocity and exchange (of persons, land and objects), but the actual interlocutors of these processes-the navugu and natau-are contingent parts, rather than unyielding, ahistorical wholes. The people of Big Bay are well aware that their kin groups are subject to emergence and disappearance at different spatial and temporal junctures. In other words, while the binary exchange of people and land is modelled on dualistic oppositions, these oppositions are subject to the contingent, historically and morally inflected unfolding movement of persons and things in time and space. Thus, rather than thinking of them as unyielding structures, the binaries at issue are subject (quite often, in fact) to the subversions and modifications that accompany actual political, social and environmental negotiations. In that sense, these genealogical origin stories offer us a window into the values and behavioural prescriptions that contemporary islanders tend to evoke when expressing their relations to the things of the North Santo waterscape.

The ancestral human-environmental entanglements outlined in relation to important sites of the North Santo waterscape are further informedor, following my chosen analytical frame, 'layered'-by the enormous historical and Biblical purport that the communities of Big Bay attribute to the name of the Jordan River, following its presence in Christian scripture and its consequent association with the imagined landscape of the Christian Holy Land. Moreover, in the experience and presentations of North Santo people, these Biblical associations are inseparable from highly charged political processes, wherein the contested Christian past of Santo has recently become a crucial element in contemporary islanders' strategies of political and cultural differentiation in relation to the provincial and national frameworks of state power within which they are also enmeshed. ${ }^{10}$

10 See Luque and Mondragón (2005), and especially Mondragón (forthcoming), for a detailed breakdown of North Santo representations of the contested Christian past. 


\section{A Christian Toponymical Vignette}

In April 2012, during a long conversation with Cirilo Palo, an influential knowledge expert of North Santo, I was offered the 'customary' name of Santo Island. The kastom name of Santo, Cirilo declared, was Yeven. 'It sounds like "heaven", doesn't it?' he added, in a conspiratorial tone. 'What local language does this name belong to?', I asked. ${ }^{11}$

We don't really know any more. It's an old name. But for Christians [i.e. most local people, including himself], it is a powerful name. When the first white men, the Spanish, heard this name, they naturally chose Santo as the place where they would introduce Christianity to Vanuatu. That's why they gave the name 'New Jerusalem' to the settlement that they established in Big Bay, and the name 'Jordan' to the island's big river. They realised this was a special land. A holy land. The great southern land of the Holy Spirit. ${ }^{12}$

During our conversation, olfala ('elder') Cirilo added that few people today remember the kastom name for Santo-and this makes it all the more powerful. ${ }^{13}$ His toponymical revelation was unexpected; in 10 years of tramping around North Santo, I had never registered a kastom name for the island. That it was unexpected, however, does not mean that it was extraordinary. As I have since discovered, Yeven is not a secret or restricted name, to be kept from public conversation. Its principal quality seems to be that it offers an important, shared link to an imagined Christian geography. As Cirilo observed, it is a powerful name, and in this regard

11 Cirilo is a resident of Port Olry, a community of east coast Santo that came into being in the first half of the twentieth century as the result of a mass, planned migration from people in Tolomako, on the southwestern corner of Big Bay. This means that his mother tongue is most likely Tolomako, but he is also fluent in the Sakao language of Olry, and quite possibly one or two other local languages. With regard to the name Yeven, this was not the first time that I found myself trying to obtain a narrow, concrete meaning for what has proven to be a widespread but polysemic category across different communities of North Santo.

12 Cirilo was drawing from the common translation, rendered into Bislama from English, of the original name given to Santo by Quirós_-'La Australia del Espíritu Santo'. See Luque and Mondragón (2005) for a detailed analysis of the acts of naming and appropriation performed by the Quirós expedition.

13 Not coincidentally, Cirilo is one of the few who can still evoke it, to full rhetorical effect - as I witnessed one day later, when we discussed it with a group of Santo Islanders who passed through his village on the way to a Presbyterian Church meeting in the south of Santo. When asked about the name, and whether they knew it or could elaborate on its meaning, they confessed their ignorance, but immediately came to the same association with 'heaven' that Cirilo had proffered, and were quite ready to entertain the thought that it partly accounted for the fact that Santo was the first place where Christianity was introduced into Vanuatu. 
it constitutes a key term in the 'ever-shifting social geometry of power and signification' (Pannell 2007: 74) by which the people of North Santo 'make persons' and 'make place'.

In a similar vein, New Jerusalem is important because it was the name given by the first Europeans to intrude on Vanuatu, when they came ashore at the site on which the present-day village of Matantas was built. In the words of olfala Cirilo:

The chief in charge of guarding this ground [Matantas and its surroundings], whom the Spanish killed long ago, he was a great chief. He had a name. No one remembers it now. But I do. Because it is my responsibility. He was known as chief Masorow. His matriline [natau] survives. His descendants are still here. (Cirilo Palo, personal interview, March 2010)

Given their close association with the first arrival of Christianity, a decisive event in most ni-Vanuatu reconstructions of the local and national past, it should not be surprising that names such as Yeven, Jordan and New Jerusalem represent a powerful cluster of toponyms through which North Santo people render their shared territory (as opposed to the ancestral territory of a particular matriline) as a unique space of spiritual and historical purport in relation to the southern part of the island and Vanuatu more generally.

Importantly, one of these toponyms does not refer to a 'grounded' part of the landscape (variously venue, vanua, venie or fana), but to a body of water (nepe in several local languages). By evoking the customary name for the River Jordan in the same breath with that of Santo, olfala Cirilo provided a useful reminder about why the circumambient world of North Santo cannot be adequately approached by understanding it principally as a 'landscape': the emphasis on 'land' eschews the subtle but powerful intertwined presence and effect of the various elements of the 'waterscape' that constitute the islanders' lived worlds.

Given that they are the primary sites of the waterscape in which the stories and people that I mention in this chapter live, it is convenient to turn again to the Jordan River, and more broadly to Big Bay, which is an extraordinary (in the sense of very large and unique) part and product of the watershed of the Jordan. 


\section{The Jordan Basin: Shared History and Watery Sites of Power}

The River Jordan, like the kastom name for Santo, represents a key element of the layered topogeny, 'the recitation of an ordered sequence of place names' (Fox 2006: 8), through which the people of North Santo anchor and act upon their landscapes and seascapes. In terms of the 'moral dimensions' of the local waterscape that I have mentioned previously, the Jordan is recognised as an especially powerful marker for claims to spiritual (religious) and political authority - that is to say, for 'truth' statements regarding knowledge of the moral, spatial and temporal qualities of the networked social and spiritual elements that constitute the Christian aspects of the history and geography of North Santo.

The broader scenario in which this history and geography is rooted is Big Bay, which constitutes one of the three major component areas of North Santo that I described at the beginning of this chapter. As explained previously, these consist of the western and eastern coasts and Big Bay proper. Here, however, I would offer a different way of typifying this region, in order to better highlight the positioning of peoples in relation to the Jordan basin. Rather than speak of east and west, I would concentrate on the contrast between the interior or 'bush' Santo, in which the sources and upper tributaries of the Jordan are located, and the coast. This contrast is not based on a radical opposition, but rather on a complementary relationship. From a coastal perspective, Big Bay emerges as an extension of the interior, insofar as it gives form to the lower reaches of the Jordan watershed.

'Bush' Santo, as I define it here, encompasses the largely inaccessible and extremely rugged mountainous interior through which the River Jordan runs; its soils and territory are constitutive of the overall basin, which is characterised by an extensive alluvial fan that empties out into the flatlands and marshes that make up the various 'mouths' of the Jordan. This latter zone comprises a shifting delta of rivulets that empty out into Big Bay. Importantly, because the mouth of the Jordan lies virtually at the centre of the bay itself, it neatly bisects the shoreline into an eastern and a western sector, each of which represents an important sub-region by which local communities define their sense of geographical belonging. 
The alluvial terrain carved out by the Jordan basin, through which 'bush' Santo gradually descends, is more broadly flanked, to the east and the west, by the two extended peninsular mountain ranges of the Cumberland Peninsula and the Sakao Peninsula, whose vertical contours jut out into the northern sea, giving Santo Island its peculiar U-shape. The inward-facing sides of this U-shaped mountainous terrain frame and enclose Big Bay proper, while the exterior, seaward-facing sides of the Cumberland range and Sakao Peninsula give rise to markedly different physical and social coastal environments, known commonly as 'West Coast Santo' and 'East Coast Santo'. When viewed in contrast with the waters and coasts of Big Bay, it is easier to understand that the histories and networks of interaction of these two coastal regions are different insofar as, in addition to their inland connections, they have also been strongly oriented towards the open sea and other coasts and islands. Theirs is indeed a different waterscape from the one at issue in this chapter.

The above typifications should be understood not as geographic mirror images of local social boundaries, but as aspects of the genealogical entanglements that simultaneously link and separate 'upper' from 'coastal' peoples, or 'inward' from 'seaward' communities. Part of what I am trying to convey with these contrasts is a sense of the rich and changing patterns by which the settlements and language groups of the lower Jordan extend into and overlap with those of bush Santo. One of the forms that these entanglements take, in contemporary North Santo experience, is a shared sense of regional solidarity, as informed by recent events relating to the imagined past.

In terms of their place in the broader picture of Vanuatu's national history, the shared political and economic point of view of 'bush' and coastal North Santo communities rests on their perception of their region as a victimised landscape. As I explain in another text (Mondragón forthcoming), this forlorn image of their shared territory is largely a result of many North Santo communities having been on the losing side of the Santo rebellion of 1980 (Beasant 1984). The subsequent marginalisation of North Santo from the flows of wealth, development and political power following Independence has motivated both a regional sense of victimhood and the development of highly assertive and self-reliant forms of cultural and territorial identity. Across almost every language group in Big Bay, people 
keenly oppose the solidarity of North Santo to the historical development and ongoing interests of the southern half of the island, and indeed of the Vanuatu state as a broader, encompassing entity. ${ }^{14}$

The proximate manifestation of the post-Independence state into which many North Santo Islanders feel they were pulled against their will is the provincial bureaucracy of Sanma Province, with its headquarters in the distant, urbanised and increasingly wealthy township of Luganville. At the same time, beneath this sense of shared regional identity lies a tapestry of fascinating, largely untold microhistories of movement, conflict, belonging and resistance that give rise to the patchwork of different human communities and local environs of North Santo. This patchwork is susceptible to a variety of approaches or descriptions, none of which can aspire to constitute a totalising map since it encompasses innumerable life stories and localities. Some of these could include the hillside or coastal communities of the Cumberland Peninsula, with their roots in water taro and the enormous irrigated terraces in which their local staple has thrived for hundreds of years. It could also include the families of bush Santo who moved from under the shadow of Tabwemasana and onto the coastal lands abandoned by Tolomako people in the first half of the twentieth century, during the period in which the members of this latter community migrated en masse to the new town of Port Olry. The North Santo tapestry also includes the scattered lowland matrilines that make their home near the swampy banks of the mouths of the Jordan: some of these settlements are recent, having been founded by converts to new Pentecostal and other Christian denominations in the 1970s and 1980s. Conversely, there are longstanding communities that came together over a century ago as a result of conversion. Such are the Anglican folk of Tseriviu, near the middle of the Cumberland Peninsula facing Big Bay, or the extended network of Catholic villages that dot the landscape north of Tseriviu, all the way to Péséna, and thence hook up with the local diocesan headquarters in Port Olry. Finally, this map of interregional diversity would also include the small, isolated village of Hokwa, at the very northern tip of the Cumberland Peninsula, whose language is quite unlike the other North Santo languages, but whose people exhibit mythical and linguistic affinities with the inhabitants of the Torres Islands, over $100 \mathrm{~km}$ away across the open sea. ${ }^{15}$

14 For more on the victimised landscapes and microhistories that I am evoking here, see Brooks et al. (2008) and Stoler (2013).

15 Hence my surprise when, during a brief visit to Hokwa, I discovered that I could understand their vernacular speech. 
This shifting patchwork of interregional pluralities of language, kinship and territory is powerfully shaped by —and rooted in - the geography of the Jordan watershed and its neighbouring ecologies. From this physical perspective, North Santo emerges as a unique, rugged world that continues to be difficult to access. Beyond the village of Tolomako and the mouths of the Jordan there are no more roads. The mountainous terrain and the multifarious, watery landscape (pools, marshes, waterfalls, swift creeks) have both shielded and excluded many North Santo peoples from the 'development' of other regions. It has also fostered a strong sense of selfreliance that works as a marker of shared histories and belonging.

In the final paragraphs of this chapter, I focus on the micro-historical perspective of a prominent North Santo community, the village of Matantas. My choice of Matantas derives, on one hand, from its past and present importance as a socio-geographical crossroads, a site of relevance within the kin and exchange networks that criss-cross Big Bay. It is also a site of critical importance in terms of the imagined Christian past of Santo-and indeed of Vanuatu as a whole (Jolly 2006; Mondragón forthcoming). There is, however, another reason for the relevance of Matantas in the regional imagination-a reason that takes us back to North Santo accounts of power, landscape and water.

As registered in conversation with many different North Santo people, there is a common perception that Matantas is a place of great spiritual power and danger. It is a taboo place whose most important toponymical marker is a spring that gives rise to the small creek from which Matantas gets its name-mata ('eye') plus natas ('salt water'). This creek is said to be the overflow from a massive, supernatural source of salt water that holds up the island of Santo from the inside. It is opposite and complementary to the source of fresh water from which the River Jordan springs, further up in the rugged mountains of the interior. It is a small but permanent manifestation of the broader powers of the physical cosmos, which has survived earthquakes, migrations, tidal waves, the disturbances of colonial plantation activity and other recent ways in which Europeans have continued to impress their notions of nature and history upon the local landscape. As such, it is a site that demands to be respected, honoured and feared.

The spiritual guardian of the Matantas spring is an ancestral woman, an origin spirit of the kind who created the basic things of the world: water, stones and the first ancestors of every human lineage. She resides, in stone form, at the bottom of the spring; awake and alert to the goings on of 
the world. Over the past four decades, this guardian spirit has intervened several times in the affairs of Matantas people: during the founding of the modern village in the mid-1970s, when she haunted those whom she would not tolerate as residents of this taboo ground; and during the opening of the dirt track in 1977, when she murdered several of the local and foreign people who were involved in the construction of the road. That road was not meant to be, because it represented the beginning of systematic intrusions from the south, and Matantas people have continued to make offerings and special forms of supplication to the guardian spirit in order to placate her anger at this increasingly busy road. The spirit was also present more recently, when she haunted a Canadian agricultural engineer who came to Matantas to try to implement a Chinese-funded pilot project for introducing rice paddies into local horticultural practices.

Finally, it is likely that the mythical purport of its guardian spirit is entangled with contemporary ways of situating Matantas in relation to the broader genealogical history of North Santo. Here, again, it is worth quoting Cirilo Palo, given his widely recognised authority on the layered stories of the land and people of North Santo:

Matantas is the common ground of every matriline in Big Bay ... It is the 'mama ground', the foundational territory of every matriline in Big Bay. We all originally came from there; the founding ancestresses of every matriline came from there. So [...] this place ... it is different from all others. You see a settlement there today, but in the past it was not inhabited. It was taboo ground.

\section{Conclusion}

In another text, I describe the 'living milieu' of North Vanuatu societies as a complex interweaving of land- and seascapes, personhood, and "topogeny" [that] is continuously imagined and reiterated through flows of persons and things as a self-productive process that [as Biersack notes] gives rise to a "life-world of praxis and not just signification"' (Mondragón 2009: 116). In this chapter, I have explored the River Jordan's lower catchment basin from perspectives that incorporate the interweaving of watery geographies and genealogies as multi-layered 'horizons of agency' (Biersack 1990), in which persons and environments are in constant motion and transformation. In this regard, my materials are intended as an extension of a broader set of reflections about the humanised landscapes and seascapes of Vanuatu. 
I have focused on how fresh water in its various forms is entangled with genealogical networks of people, presences and storied places that make up North Santo. To this end, I presented an outline-the first of its kind in the local ethnographic record - of the relationship between moiety and lineage names and the animals and places of the waterscape of North Santo. I thereby explored how water gives shape to powerful spirit presences-presences that, as in the case of the Piavohoho River and the spirit of the waterfall at Septualahia, serve as reminders of morally correct behaviour and genealogical chains of belonging. But I have also highlighted the presence of even greater primordial spirits, such as that of Matantas, whose perceived power extends to the origin story of Santo Island as a whole and continues to exert a forceful presence in contemporary affairs.

Finally, I explored waterscapes in relation to culture contact and history. History here can take the form of ancestral topogenies, or the imagined Christian past in the present, as well as of contemporary senses of marginalisation in relation to foundational events in the nation's history. I have thereby produced one of the first multilayered outlines of the North Santo context as a region that is profoundly and powerfully defined in relation to its watershed. The consequent image is of a unique, insular watershed, whose multiple, interleaving strands remind us that rivers, and fresh water more generally, are also critical components of Melanesian and Oceanic ways of making people and places.

\section{References}

Baviskar, A., 2007. Waterscapes: The Cultural Politics of a Natural Resource. Delhi: Permanent Black.

Beasant, J., 1984. The Santo Rebellion: An Imperial Reckoning. Honolulu: University of Hawai i Press.

Biersack, A., 1990. 'Histories in the Making: Paiela and Historical Anthropology.' History and Anthropology 5: 63-85. doi.org/10.1080/02757 206.1990.9960808

Bonnemaison, J., 1994. The Tree and the Canoe. Honolulu: University of Hawai' $\mathrm{i}$ Press.

—_ 1996. Gens de Pirogue et Gens de la Terre: Essai de Géographie Culturelle Livre I. Paris: ORSTOM Éditions. 
, 1997. 'Les Lieux de l'Identité: Vision du Passé et Identité Culturelle dans les Îles du Sud et du Centre de Vanuatu (Mélanésie).' In E. Bernus, J. Polet and G. Quéchon (eds), Autrepart. Empreintes du Passé. Paris: Éditions de l'Homme/ORSTOM.

Boomgarden, P. (ed.), 2007. A World of Water: Rain, Rivers and Seas in Southeast Asian Histories. Leiden: KITLV Press. doi.org/10.26530/OAPEN_376971

Brooks, J., C.R. DeCorse and J. Walton (eds), 2008. Small Worlds: Method, Meaning, and Narrative in Microhistory. Santa Fe (NM): School for Advanced Research Press.

Fox, J.J., 2006 [1997]. 'Place and Landscape in Comparative Austronesian Perspective.' In J.J. Fox (ed.), The Poetic Power of Place: Comparative Perspectives on Austronesian Ideas of Locality. Canberra: ANU E Press.

Guiart, J., 1958. Santo (Nouvelles Hébrides). Paris: Plon.

Hess, S., 2009. Person and Place: Ideas, Ideals and the Practice of Sociality on Vanua Lava, Vanuatu. New York: Bergahn Books.

Jolly, M., 1999. 'Another Time, Another Place.' Oceania 69: 282-299. doi.org/ 10.1002/j.1834-4461.1999.tb00374.x

__ 2006. 'Unsettling Memories: Commemorating "Discoverers" in Australia and Vanuatu.' In F. Angléviel (ed.), Pedro Fernández de Quirós et le Vanuatu: Découverte Mutuelle et Historiographie d'un Acte Fondateur, 1606. Port Vila: Délégation de la Commission Européenne au Vanuatu.

Lane, R., 1971. 'The New Hebrides: Land Tenure without Land Policy.' In R. Crocombe (ed.), Land Tenure in the Pacific. Melbourne: Oxford University Press.

Luque, M. and C. Mondragón, 2005. 'Faith, Fidelity and Fantasy: Don Pedro Fernández de Quirós and the "Foundation, Government and Sustenance" of La Nueba Hierusalem in 1606.' Journal of Pacific History 40: 133-148. doi.org/10.1080/00223340500176368

Lynch, J. and T. Crowley, 2001. Languages of Vanuatu: A New Survey and Bibliography. Canberra: The Australian National University, Research School of Pacific and Asian Studies (Pacific Linguistics 517).

MacClancy, J., 2002. To Kill a Bird with Two Stones: A Short History of Vanuatu. Port Vila: Vanuatu Cultural Centre. 
Mondragón, C., 2009. 'A Weft of Nexus: Geographical Identity and Changing Notions of Space in Vanuatu, Oceania.' In P.W. Kirby (ed.), Boundless Worlds: An Anthropological Approach to Movement. New York: Berghahn Books.

, 2012. 'Entre Islas y Montañas: Movimiento y Geografía Cultural en Melanesia y el Tibet.' In C. Mondragón, P. Fournier, and W. Wiesheu (eds), Peregrinaciones Ayer y Hoy. México: El Colegio de México (Antropología y Arqueología de las Religiones 4).

—_, 2015a. Un Entramado de Islas: Persona, Medio Ambiente y Cambio Climático en el Pacifico Occidental. Mexico: El Colegio de México.

—, 2015b. Concealment, Revelation and Cosmological Dualism: Visibility, Materiality and the Spiritscape of the Torres Islands, Vanuatu. Paris: Éditions l'Herne/College de France (Cahiers d'Anthropologie Sociale).

—, forthcoming. "The Troubled Image of a Biodiversity "Hotspot": Conservation, Christianity and History in Santo, Vanuatu.' In J. Bell and J. Halvakzs (eds), Naturalist Histories.

Pannell, S., 2007. 'Of Gods and Monsters: Indigenous Sea Cosmologies, Promiscuous Geographies and the Depths of Local Sovereignty.' In P. Boomgaard (ed.), A World of Water: Rains, Rivers and Seas in Southeast Asian Histories. Leiden: Brill. doi.org/10.1163/9789004254015_004

Rodman, M., 1987. Masters of Tradition: Consequences of Customary Land Tenure in Longana, Vanuatu. Vancouver: University of British Columbia Press.

Siméoni, P., 2009. Atlas du Vanouatou. Port Vila: Éditions Géo-Consulte.

Stoler, A.L. (ed.), 2013. Imperial Debris: On Ruins and Ruination. Durham (NC): Duke University Press. doi.org/10.1215/9780822395850

Taylor, J., 2008. The Other Side: Ways of Being and Place in Vanuatu. Honolulu: University of Hawai'i Press. doi.org/10.21313/hawaii/ 9780824833022.001 .0001

Tryon, D., 1996. 'Dialect Chaining and the Use of Geographical Space.' In J. Bonnemaison, C. Kaufmann, K. Huffman and D. Tryon (eds), Arts of Vanuatu. Bathurst (NSW): Crawford House Press.

Tzérikiantz, F., 2008. 'Sevrapek City ou La Courte Histoire du Groupe de Recherche "Forêts Montagnes-Rivières" (Expédition Santo 2006, Vanuatu).' Journal de la Société des Océanistes 126/7: 207-220. doi.org/10.4000/jso.3602 
This text is taken from Island Rivers: Fresh Water and Place in Oceania, edited by John R. Wagner and Jerry K. Jacka, published 2018 by ANU Press, The Australian National University, Canberra, Australia.

doi.org/10.22459/IR.06.2018.03 